\title{
Influence of Sorghum Kafirin on Serum Lipid Profile and Antioxidant Activity in Hyperlipidemic Rats (In Vitro and In Vivo Studies)
}

\author{
Raquel A. Ortíz Cruz, ${ }^{1}$ José L. Cárdenas López, ${ }^{1}$ \\ Gustavo A. González Aguilar, ${ }^{2}$ Humberto Astiazarán García, ${ }^{2}$ Shela Gorinstein, ${ }^{3}$ \\ Rafael Canett Romero, ${ }^{1}$ and Maribel Robles Sánchez ${ }^{1}$ \\ ${ }^{1}$ Departamento de Investigación y Posgrado en Alimentos, Universidad de Sonora, Boulevard Luis Encinas y Rosales, \\ Colonia Centro, 83000 Hermosillo Sonora, SON, Mexico \\ ${ }^{2}$ Centro de Investigación en Alimentación y Desarrollo, A.C. (CIAD, A.C.), Carretera a La Victoria, \\ Km 0.6, 83304 Hermosillo Sonora, SON, Mexico \\ ${ }^{3}$ Institute for Drug Research, School of Pharmacy, The Hebrew University of Jerusalem, P.O. Box 12065, 91120 Jerusalem, Israel
}

Correspondence should be addressed to Maribel Robles Sánchez; rsanchez@guayacan.uson.mx

Received 26 May 2015; Revised 23 September 2015; Accepted 29 September 2015

Academic Editor: Pengjun Shi

Copyright (C) 2015 Raquel A. Ortíz Cruz et al. This is an open access article distributed under the Creative Commons Attribution License, which permits unrestricted use, distribution, and reproduction in any medium, provided the original work is properly cited.

The aim of this study was to compare in vitro the antioxidant potential of sorghum kafirin and sorghum flour and their influence on lipids and antioxidant capacity in rats. The antioxidant activity in sorghum kafirin extract measured by the DPPH and TEAC methods was increased 30 and 65 times, respectively, compared to that of its counterpart, sorghum flour. According to electrophoresis assay, the kafirins tert-butanol extract showed a high proportion of $\alpha$-kafirin monomers, and its amino acid composition revealed higher hydrophobic amino acid content such as alanine, isoleucine, leucine, tyrosine and phenylalanine than sorghum flour extract. Diets supplemented with sorghum kafirin extract have improved lipid metabolism and increased the serum antioxidant potential (67\%) especially in rats fed with added cholesterol. The bioactive peptides generated from kafirin in vivo hydrolysis appear to be associated with the positive effect on serum lipids and antioxidant activity. According to these results, sorghum kafirin extract at the levels used in this study apparently could be used for prevention of atherosclerosis and other chronic diseases.

\section{Introduction}

Cardiovascular disease (CVD) is the most common cause of death in Mexico and atherosclerosis is the most prevalent CVD in the adult population, while coronary heart disease (CHD) is its most frequent and lethal form $[1,2]$. The main risk factor of CVD is dyslipidemia characterized by elevated total cholesterol (TC), low density lipoprotein cholesterol (LDL-C) and triglyceride (TG) levels, and decreased high density lipoprotein cholesterol (HDL-C) levels [3]. Oxidative stress may play a critical role in the pathophysiology of CVD and several epidemiological studies have shown an association between circulating antioxidants and cardiovascular diseases [4-6]. Several investigations have found an association between whole grain intake and CVD reduction [7-9]. Phenolic compounds present in grains are responsible for this protecting effect, and also some proteins and their peptides have been recognized for their biological activity $[10,11]$.

Sorghum is studied because of its high content of fiber, protein, mineral, and polyphenol content, and several studies have shown its possible role in the cardiovascular disease prevention $[12,13]$. In vitro hydrolysis of sorghum protein has been studied for to its peptides and their relationship 
to antiviral [14] and antihypertensive activities [15]. These activities are attributed to fractions isolated from $\alpha$-kafirin, the main storage protein in sorghum. The mechanisms by which kafirin can exert a protective effect start with hydrolysis and the absorption of biologically active peptides or amino acids, that can affect biological processes including the body function or health status [16].

Antioxidant activity is defined as the property that some chemicals have in quenching free radicals by donating a proton or hydrogen atom. Free radicals can oxidize biological structures such as lipids, which once oxidized can cause alterations in the cell membrane, while that their oxidation products can promote the development of atherogenic processes $[17,18]$. It is possible that the enzymatic digestion of sorghum kafirins in an in vivo model may promote the production of bioactive peptides with antioxidant activity that can be absorbed and passed into the bloodstream, leading to a beneficial effect on its lipid profile. The aim of the study was to evaluate the in vitro potential antioxidant of sorghum kafirin extract as compared with sorghum flour and their effect on lipid profile and antioxidant activity in serum of hypercholesterolemic rats. The findings of this study are determinant in further understanding and development of this nonconventional cereal to be used in treatment of CVD.

\section{Materials and Methods}

2.1. Materials and Chemicals. Sorghum (Sorghum bicolor L. Moench) white variety UDG-110 was provided by Fundación Produce, Mexico. Cholesterol, 6-hydroxy2,5,7,8-tetramethylchroman-2-carboxylic acid (Trolox), 2,2azino-bis (3-ethylbenzthiazoline-6-sulfonic acid) (ABTS), 1,1-diphenyl-2-picrylhydrazyl (DPPH), fluorescein (FL), and 2,2'-azo-bis (2-amidinopropane) dihydrochloride (AAPH) were purchased from Sigma Chemical Co., St. Louis, MO, USA. Total cholesterol (TC), low density lipoprotein cholesterol (LDL-C), high density lipoprotein cholesterol (HDL-C), and triglyceride kits were acquired from RANDOX. Unless otherwise specified, all chemicals and solvents were of analytical grade. Sorghum flour (SF) (9.25\% total protein dry matter basis) was obtained from whole grain using a laboratory mill (Laboratory Mill 1100), fitted with a $0.5 \mathrm{~mm}$ opening screen.

2.2. Extraction of Kafirins. The method of Mazhar et al. [19] was used for the extraction of kafirins. In brief, $100 \mathrm{~g}$ of defatted sorghum flour was mixed with $500 \mathrm{~mL} 60 \%$ tertbutanol/water at $37^{\circ} \mathrm{C}$ and vigorously stirred for $6 \mathrm{~h}$. After centrifugation, the tert-butanol was evaporated to recover the supernatant. The aqueous supernatant containing kafirins was freeze-dried and named SK. The protein content of the SK was $40 \%(N \times 6.25$, dry matter basis $)$.

2.3. Sodium Dodecyl Sulfate Polyacrylamide Gel Electrophoresis. The SK was characterized by sodium dodecyl sulfate polyacrylamide gel electrophoresis procedure (SDS-PAGE) on $4-12 \%$ acrylamide gradient gel under reducing conditions [20, 21]. All gels were stained with Coomassie brilliant blue stain R-250 at $0.125 \%$. The low MW markers (BIO-RAD) for gel electrophoresis were albumin $(66 \mathrm{kDa})$, ovalbumin $(45 \mathrm{kDa})$, glyceraldehyde 3 -phosphate dehydrogenase $(36 \mathrm{kDa})$, carbonic anhydrase $(29 \mathrm{kDa})$, trypsinogen $(24 \mathrm{kDa})$, trypsin inhibitor $(20.1 \mathrm{kDa})$, and lactalbumin $(14.4 \mathrm{kDa})$. Gels were analyzed with a GS-800 Bio Rad Densitometer using Quantity One version 4.6.9 software.

2.4. Amino Acid Composition Analysis. Amino acid analysis of samples of SF and SK was based on the methodology previously reported [22]. Briefly, powered samples (3 mg) were hydrolyzed with $\mathrm{HCl}(6 \mathrm{~N})$ at $150^{\circ} \mathrm{C}$ during 12 hours. After hydrolysis, the acid was removed by rotary evaporation and the sample was resuspended on $2 \mathrm{~mL}$ of sodium citrate buffer $\mathrm{pH}$ 2.2. The HPLC method precision and accuracy was evaluated using external and internal standards. The amino acid reference standard consisted of sixteen amino acids $\left(0.05 \mu \mathrm{moles} \mathrm{mL}^{-1}\right.$ each amino acid) and was utilized to determine the retention times for each amino acid. Internal standard $\alpha$-aminobutyric $\left(0.05 \mu\right.$ moles $\left.\mathrm{mL}^{-1}\right)$ was added to amino acid reference standard and each sample to normalize and quantify the amino acid content. A gradient mobile phase of sodium acetate $0.1 \mathrm{M}$ pH 7.2 and methanol $(9: 1)$ elute sample for amino acid separation through $\mathrm{C} 18$ column reversed-phase octadecyl dimethylsilane particles $(100 \times$ $4.6 \mathrm{~mm} \times 1 / 4^{\prime \prime}$ Microsorb 100-3 C18). Fluorescence detection was performed using an excitation emission wavelength of 360 and $455 \mathrm{~nm}$, respectively. Star Chromatography work station (Varian version 5.51) software was used to achieve amino acid peak integration. The results (amount of amino acids $\mathrm{g} / 100 \mathrm{~g}$ of protein) listed in Table 2 are means of three replications and coefficient of variation was lower than $5 \%$.

2.5. Trolox Equivalent Antioxidant Capacity (TEAC). This assay is based on the ability of antioxidants to scavenge the blue-green $\mathrm{ABTS}^{\circ+}$ radical cation, relative to the $\mathrm{ABTS}^{\bullet+}$ scavenging ability of the water-soluble vitamin $\mathrm{E}$ analogue Trolox. The $\mathrm{ABTS}^{\bullet+}$ radical cation was generated by the interaction of $5 \mathrm{~mL}$ of $7 \mathrm{mM}$ ABTS solution and $88 \mu \mathrm{L}$ of $140 \mathrm{mM} \mathrm{K}_{2} \mathrm{~S}_{2} \mathrm{O}_{8}$ solution. After the addition of $3.9 \mathrm{~mL}$ of $\mathrm{ABTS}^{\bullet+}$ solution to $0.1 \mathrm{~mL}$ of methanolic (SF) or tert-butanol (SK) extracts or Trolox standards ( 0 to $20 \mu \mathrm{M}$ range), the absorbance was monitored exactly 1 and $30 \mathrm{~min}$ after the initial mixing. The percentage of absorbance inhibition at $734 \mathrm{~nm}$ was calculated and plotted as a function obtained for the extracts and the standard reference (Trolox). The final TEAC values were calculated by using a regression equation between the Trolox concentration and the inhibition percentage and expressed as millimol of Trolox equivalents per $\mathrm{g}$ of dry weight [23].

2.6. DPPH Assay. This assay is based on the measurement of the scavenging ability of antioxidants towards the stable radical DPPH relative to the $\mathrm{DPPH}$ scavenging ability of the water-soluble vitamin E analogue Trolox. Briefly, $3.9 \mathrm{~mL}$ aliquot of DPPH $(0.0634 \mathrm{mM})$ solution was added to the test 
TABLE 1: Percent composition of experimental diets.

\begin{tabular}{lccccc}
\hline Components & Con & Chol & $\begin{array}{c}\text { Chol/ } \\
\text { SF5 }\end{array}$ & $\begin{array}{c}\text { Chol/ } \\
\text { SF10 }\end{array}$ & $\begin{array}{c}\text { Chol/ } \\
\text { SK0.25 }\end{array}$ \\
\hline Corn starch & 69.1 & 68.1 & 63.1 & 58.1 & 67.85 \\
Casein & 15 & 15 & 15 & 15 & 15 \\
Soybean oil & 10 & 10 & 10 & 10 & 10 \\
Cellulose & 1 & 1 & 1 & 1 & 1 \\
Mineral mixture & 3.7 & 3.7 & 3.7 & 3.7 & 3.7 \\
Vitamin mixture & 1 & 1 & 1 & 1 & 1 \\
Choline & 0.2 & 0.2 & 0.2 & 0.2 & 0.2 \\
Cholesterol & - & 1 & 1 & 1 & 1 \\
Sorghum flour (SF) & - & - & 5 & 10 & - \\
Sorghum kafirin (SK) & - & - & - & - & 0.25 \\
\hline
\end{tabular}

Con: control diet group; Chol: cholesterol diet group; Chol/SF5: 5\% sorghum flour diet group; Chol/SF10: 10\% sorghum flour; Chol/SK: 0.25\% sorghum kafirin diet group.

tubes and $0.1 \mathrm{~mL}$ of methanolic (SF) or tert-butanol (SK) extracts or Trolox standards ( 0 to $20 \mu \mathrm{M}$ range) was added and shaken vigorously. The tubes were allowed to stand at $27^{\circ} \mathrm{C}$ for $60 \mathrm{~min}$. A control reaction was prepared as above without any extract, and methanol was used for the baseline correction. Changes in the absorbance of the samples were measured at $515 \mathrm{~nm}$. Radical-scavenging activity was expressed as the inhibition percentage. The final DPPH values were calculated by using a regression equation between the Trolox concentration and the inhibition percentage and expressed as millimol of Trolox equivalents per $g$ of dry weight [23].

2.7. Animals and Diets. All experimental procedures were approved on August 1, 2013, by the Ethics Committee of the Research Center in Food and Development (CIAD, A.C.), Hermosillo, Sonora, Mexico. The mean weight of Wistar rats ( $n=30$ ) used was $120 \mathrm{~g}$ and they were provided by the Experimental Animals Laboratory of Universidad de Sonora, Mexico. They were allowed to have free access to basal diet and tap water for 7 days before experiment. After one-week acclimatization, the rats were randomly divided into five groups ( $n=6$, each) and were given the five different dietary treatments. During 28 days period, two control groups were fed a basal diet (Con) or hypercholesterolemic diet (Chol) and the treatment groups were fed with the Chol diet plus $5 \%$ sorghum flour (Chol/SF5), Chol diet plus 10\% sorghum flour (Chol/SF10), or Chol diet plus $0.25 \%$ sorghum kafirin (Chol/SK0.25). We used $0.25 \%$ SK in Chol diet with the objective that rats had a similar amount of kafirin to that of rats fed with the lowest sorghum flour added to diet (Chol/SF5). The calculation of this \% was as follows: $100 \mathrm{~g}$ of SF contained $9.5 \%$ of total protein, where $60 \%$ is prolamin fraction $(\sim 5.7 \mathrm{~g})$. From this amount, $80 \%$ are kafirins $(\sim 4.56 \mathrm{~g})$ consequently; $5 \mathrm{~g}$ of sorghum flour has $0.25 \mathrm{~g}$ of kafirin. Table 1 shows the percent composition of the diets for each experimental group.

The cholesterol batches were mixed carefully with the basal diet just before the diets were offered to the rats. All rats were fed ad libitum once a day at 10 a.m. and the intake of
TABLE 2: Amino acid composition of sorghum flour (SF) and sorghum kafirin $(\mathrm{SK})^{1}$.

\begin{tabular}{|c|c|c|}
\hline Amino acid & \multicolumn{2}{|c|}{$\mathrm{g} / 100 \mathrm{~g}$ dry weight } \\
\hline Asparagine & 5.81 & 6.68 \\
\hline Threonine & 2.92 & 2.32 \\
\hline Serine & 3.25 & 3.29 \\
\hline Glutamic acid & 14.84 & 23.12 \\
\hline Proline & 7.21 & 3.03 \\
\hline Glycine & 6.32 & 3.20 \\
\hline Alanine & 9.24 & 14.08 \\
\hline Valine & 4.83 & 4.29 \\
\hline Methionine & 1.31 & 0.746 \\
\hline Isoleucine & 3.92 & 4.01 \\
\hline Leucine & 10.10 & 14.17 \\
\hline Tyrosine & 5.31 & 5.51 \\
\hline Phenylalanine & 5.05 & 5.79 \\
\hline Histidine & 2.22 & 1.19 \\
\hline Lysine & 3.06 & 1.01 \\
\hline Arginine & 5.70 & 3.16 \\
\hline
\end{tabular}

${ }^{1}$ Each value is the mean of three replications. The coefficient of variation was lower than $5 \%$.

the diet and body weight were monitored weekly. All rats had unrestricted access to drinking water. At the conclusion of the experiment (day 28), all groups of rats were anesthetized using diethyl ether, and blood samples were taken from the left atrium of the heart. Serum was prepared for analysis including TC, HDL-C, LDL-C, and TG as described by RANDOX Labs.

2.8. Serum Antioxidant Activity Measured by Using Oxygen Radical Absorbance Capacity (ORAC) Assay. This assay measured the effect of antioxidant components of foods or biological fluids on the decline in FL fluorescence induced by AAPH, a peroxyl radical generator. The reaction mixture contained $1.7 \mathrm{~mL}$ of $75 \mathrm{mM}$ phosphate buffer ( $\mathrm{pH} 7), 100 \mu \mathrm{L}$ of $0.0102 \mathrm{mM} \mathrm{FL}, 100 \mu \mathrm{L}$ of $320 \mathrm{mM} \mathrm{AAPH}$, and $100 \mu \mathrm{L}$ of each sample or several dilutions of the Trolox standard. FL, phosphate buffer, and samples were preincubated at $37^{\circ} \mathrm{C}$ for $15 \mathrm{~min}$. The reaction was started by the addition of AAPH, and the fluorescence was measured and recorded every $5 \mathrm{~min}$ until the fluorescence of the last reading declined to $<5 \%$ in respect to the initial reading (approximately $60 \mathrm{~min}$ ). One blank and a maximum of 12 samples were analyzed at the same time. The excitation and emission wavelength was set as 484 and $515 \mathrm{~nm}$, respectively. The final ORAC values were calculated by using a regression equation between the Trolox concentration and the net area under the FL decay curve and were expressed as millimol of Trolox equivalent per L [23]. The area under the curve (AUC) was calculated according to the following equation:

$$
\begin{aligned}
& \mathrm{AUC}=\left(0.5+\frac{\int_{5}}{\int_{0}}+\frac{\int_{10}}{\int_{0}}+\frac{\int_{15}}{\int_{0}}+\frac{\int_{20}}{\int_{0}}+\frac{\int_{25}}{\int_{0}}+\frac{\int_{30}}{\int_{0}}\right. \\
& \left.+\cdots+\frac{\int_{i}}{\int_{0}}\right) \times 5,
\end{aligned}
$$




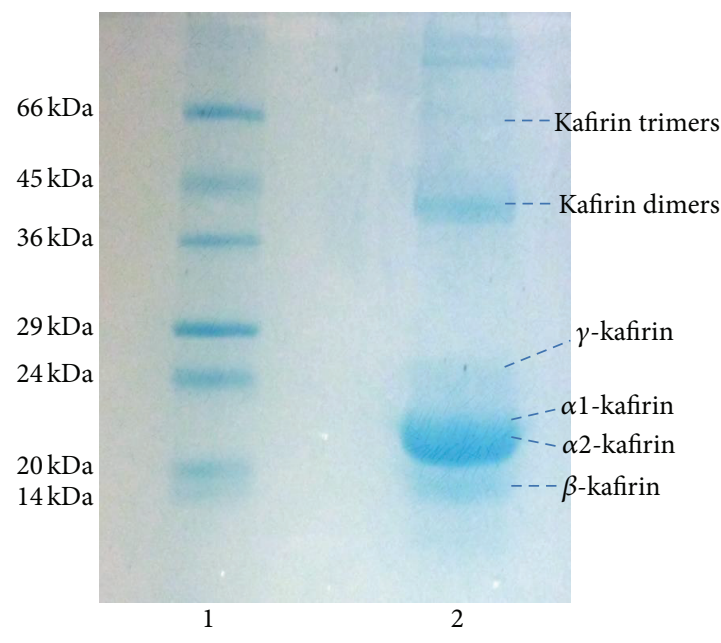

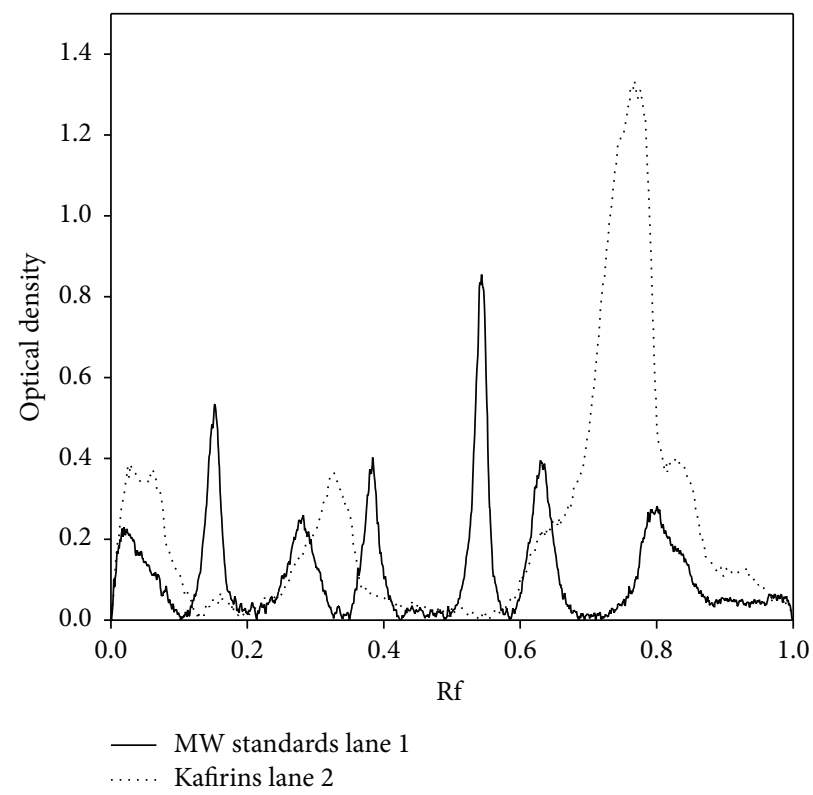

(b)

FIGURE 1: (a) SDS-PAGE pattern of kafirins from Sorghum. Lane 1: molecular weight standards; Lane 2: sorghum kafirin (SK) under reducing conditions. (b) Densitometry pattern of same 2 lanes.

where $\int_{0}$ is the initial fluorescence reading at $0 \mathrm{~min}$ and $\int_{i}$ is the fluorescence reading at time $i$. The data were analyzed by applying the equation in a Microsoft Excel spreadsheet to calculate AUC. The net AUC was obtained by subtracting the AUC of the blank from of the sample.

2.9. Statistical Analysis. The results of the in vitro study were analyzed by descriptive statistics, means $\pm \mathrm{SD}$, or coefficient of variance of three measurements. For the in vivo study, differences between groups were tested by two-way analysis of variance, followed by Tukey's multiple comparison test. The criterion for significance was $p<0.05$.

\section{Results and Discussion}

3.1. Kafirin Extraction and Composition. Kafirins were extracted with $60 \%$ tert-butanol and analyzed under reducing conditions by SDS-PAGE. Figure 1(a) shows the SDS PAGE pattern of kafirin from sorghum extract. Major bands were observed at $20-24 \mathrm{kDa}$, indicating the presence of $\alpha 1$ - and $\alpha 2$-kafirin monomers. Bands close to $19 \mathrm{kDa}$ and $27 \mathrm{kDa}$ were identified as $\beta$-kafirin and $\gamma$-kafirin polypeptides, which corresponds with previous reports [24]. In addition, two bands close to 45 and $66 \mathrm{kDa}$ were observed, suggesting the presence of dimers and trimers, respectively. These results were in agreement with the findings by Correia et al. [25] and Mehlo et al. [26] who used similar reducing conditions for the assay. Densitometry analysis showed that the $\alpha$-kafirins had the highest optical density (OD) at 1.4 which is more than threefold of the other kafirins present in the extract (Figure 1(b)). Prolamins are storage proteins in sorghum grain and constitute $60 \%$ of the total protein. Several authors have reported that $\alpha$-kafirins comprise $80-84 \%$ and $\beta$ - and $\gamma$-kafirins constitute $7-8 \%$ and $9-12 \%$ of the total monomers, respectively [27].

Among the different options that make kafirin extraction more efficient is the use of a reducing agent in addition to tert-butanol. This induces a breakage of disulfide bonds between proteins and promotes the release of more kafirin monomers. However, the use of reducing agents such as 2mercaptoethanol carries a high risk of toxicity; thus, given the goals of this study, this procedure is not considered appropriate.

Table 2 shows the amino acid composition of SF and SK samples. The amino acid composition of SF was similar to that reported by Mosse et al. [28], who studied the amino acid profile of 10 Sorghum varieties. SK showed an amino acid composition different from that of SF, resulting in higher content of hydrophobic amino acids such as alanine, isoleucine, leucine, tyrosine, and phenylalanine. Our results agree with those reported by previous studies of kafirins obtained by similar extraction procedure [29]. Electrophoresis assay and the amino acid analysis of the sorghum kafirin extract were similar to those previously reported studies [2729]. Therefore, protein obtained from Sorghum is referred to as kafirin. The extraction conditions were determinant on amino acid composition of kafirins. Nonreducing conditions and aqueous tert-butanol favored higher $\alpha$-kafirin extraction rather than $\beta$ - and $\gamma$-kafirin extraction. $\alpha$-kafirins are monomers with a high affinity to aqueous tert-butanol and are characterized by high hydrophobic amino acid content but low proline and methionine content [27, 30-32].

It has been reported that the presence of hydrophobic amino acids is an indicator of antioxidant activity in several cereals or food plants extracts [33-35]. These authors 




(a)



(b)

Figure 2: Body weight (a) and food intake (b) changes over the study period for each group of rats. Each value is the mean \pm SD ( $n=6$ ) of each dietary group.

TABLE 3: Antioxidant activity in sorghum flour (SF) and sorghum kafirin $(\mathrm{SK})^{1}$.

\begin{tabular}{lcc}
\hline Sample & DPPH & \multicolumn{2}{c}{ TEAC } \\
& \multicolumn{1}{c}{ mmol TE/g dry weight } \\
\hline SF & $0.101 \pm 0.001^{\mathrm{b}}$ & $2.74 \pm 0.04^{\mathrm{b}}$ \\
SK & $3.03 \pm 0.37^{\mathrm{a}}$ & $181.54 \pm 1.76^{\mathrm{a}}$ \\
\hline
\end{tabular}

${ }^{1}$ Each value is the mean \pm SD of three replications. Means in columns not followed by common letters differ significantly $(p<0.05)$.

reported that hydrophobic amino acids can inhibit lipid oxidation by hydrogen transference or metal chelation. However, other studies have documented that antioxidant activity increases with peptide sequences when the amino acids proline, leucine, and histidine are the most abundant $[36,37]$.

In our study, we observed that the efficacy of the sorghum flour to scavenge DPPH and ABTS radicals was lower than that of sorghum kafirin (Table 3). Antioxidant activity in sorghum flour can be attributed mainly to the presence of phenolic compounds, which are located in different proportions in the endosperm and pericarp. However, we cannot discriminate the possible contribution of some proteins and fatty acids present in sorghum flour to the antioxidant activity.

In white Sorghum, Awika et al. [38] reported lower antioxidant activity values $(6 \mu \mathrm{molTE} / \mathrm{g})$ in DPPH and TEAC assays. To our knowledge, there are no previous studies of the antioxidant activity of sorghum kafirin extract. Therefore, new information about the antioxidant properties of these proteins is being reported. Regarding the antioxidant activity of SK extract, this could be attributed essentially to the presence of hydrophobic amino acids, as seen above.

3.2. Lipid Profile and Antioxidant Evaluation. The data on body weight and food intake are shown in Figure 2. Figure 2(a) shows the overview of changes in body weight over the study period for the different rat groups; no significant differences in weight between the different groups were observed. Figure 2(b) shows that food intake was similar $(p>0.05)$ for each group. These observations indicate that the diet used in this study was well tolerated by rats.

SK supplemented diet in cholesterol fed groups after 4 weeks of feeding (Table 4) significantly hindered the rise of TC $(1.74 \pm 0.19$ versus $2.12 \pm 0.67 \mathrm{mmol} / \mathrm{L})$ and LDL$\mathrm{C}(0.84 \pm 0.14$ versus $1.33 \pm 0.81 \mathrm{mmol} / \mathrm{L})$. The same diets significantly increased HDL-C levels $(0.96 \pm 0.12$ versus $0.68 \pm$ $0.32 \mathrm{mmol} / \mathrm{L}$ ).

A different behavior was observed in SF supplemented diets in the cholesterol fed groups after 4 weeks of feeding. The mean values of TC increased in both SF5\% and SF10\% $(2.12 \pm 0.67$ to $2.75 \pm 0.26 \mathrm{mmol} / \mathrm{L},+29 \%$ and $2.12 \pm 0.67$ to $2.67 \pm 0.26 \mathrm{mmol} / \mathrm{L}$, and $+26 \%$, resp.). However, for the same diets, there was a significant increase in HDL-C content $(0.68 \pm 0.32$ to $1.50 \pm 0.17$ and $1.36 \pm 0.31$, resp. $)$.

At the end of the experiment, a significant increase in the serum antioxidant activity in the Chol/SK0.25 dietary group was observed with respect to Chol dietary group $(16.22 \pm 3.19$ versus $27.10 \pm 3.32 \mathrm{mmol} / \mathrm{L})$. However, a decrease $(p>0.05)$ in the serum antioxidant activity after completion of the trial was registered in SF (5 and 10\%) groups, with respect to Chol group diet (Figure 3 ). 
TABLE 4: Changes in the serum lipid profile of rats fed with different diets: $1 \%$ cholesterol (Chol), $5 \%$ and $10 \%$ sorghum flour, and $0.25 \%$ sorghum kafirin ${ }^{1}$.

\begin{tabular}{lccrr}
\hline Dietary group & TC & HDL-C & LDL-C & TG \\
\hline Control & & & mmol/L & $0.75 \pm 0.06^{\mathrm{b}}$ \\
Chol & $1.46 \pm 0.10^{\mathrm{d}}$ & $0.71 \pm 0.06^{\mathrm{c}}$ & $1.33 \pm 0.81^{\mathrm{a}}$ & $0.99 \pm 0.18^{\mathrm{a}}$ \\
Chol/SF5 & $2.12 \pm 0.67^{\mathrm{b}}$ & $0.68 \pm 0.32^{\mathrm{c}}$ & $1.17 \pm 0.16^{\mathrm{a}}$ & $0.75 \pm 0.32^{\mathrm{ab}}$ \\
Chol/SF10 & $2.75 \pm 0.26^{\mathrm{a}}$ & $1.50 \pm 0.17^{\mathrm{a}}$ & $1.23 \pm 0.21^{\mathrm{a}}$ & $0.80 \pm 0.09^{\mathrm{ab}}$ \\
Chol/SK0.25 & $2.67 \pm 0.26^{\mathrm{a}}$ & $1.36 \pm 0.31^{\mathrm{a}}$ & $0.84 \pm 0.14^{\mathrm{b}}$ & $0.67 \pm 0.07^{\mathrm{b}}$ \\
\hline
\end{tabular}

${ }^{1}$ Each value is the mean $\pm \mathrm{SD}(n=6)$ of each dietary group. Means in columns not followed by common letters differ significantly $(p<0.05)$.

TC: total cholesterol; HDL-C: HDL cholesterol; LDL-C: LDL cholesterol; TG: Triglycerides; Chol: nonoxidized cholesterol; SF: sorghum flour; SG: sorghum kafirin.

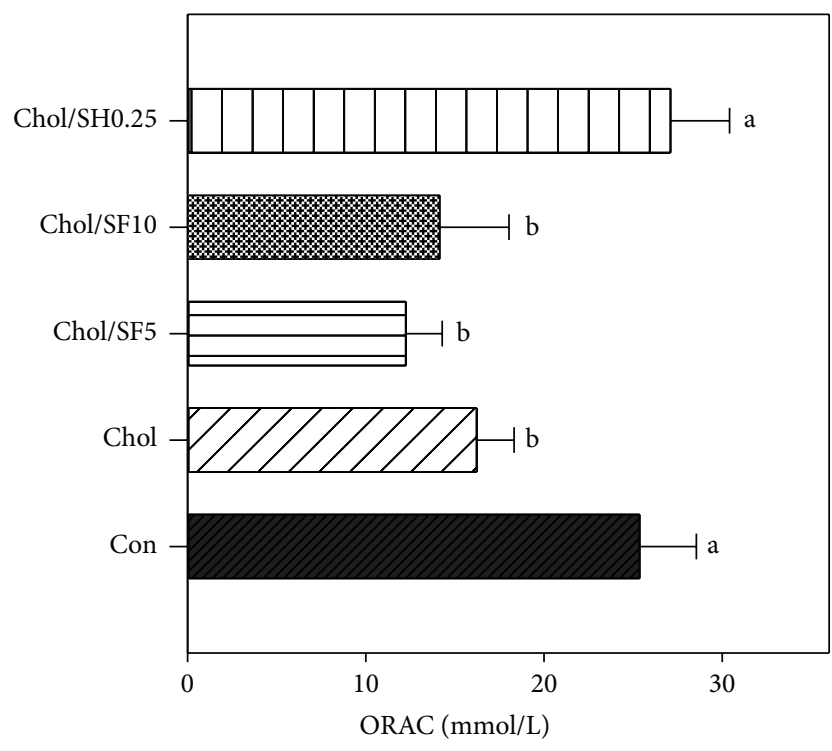

FIgUre 3: Oxygen Radical Absorption Capacity (ORAC) in rats fed with cholesterol. Each value is the mean $\pm \mathrm{SD}(n=6)$ of each dietary group. Bars with different letters are significantly different $(p<0.05)$.

This investigation has shown that sorghum kafirin positively influences the serum antioxidant activity in rats fed with added cholesterol. As far as we know, this is the first study that evaluates the in vivo changes in the lipid profile of the kafirin fractions of Sorghum. The mechanisms involved may explain that this favorable effect may be very different, ranging from a reduction in intestinal absorption of cholesterol and/or bile acids, a decrease in serum cholesterol favored by the activity of LDL receptors in the liver, and changes in the biotransformation of liver cholesterol [39].

With the results obtained in this study, we considered that kafirins could be partially hydrolyzed by digestive enzymes in the rat generating peptides that apparently are absorbed in the intestine resulting in different metabolic effects, especially in cholesterol metabolism.

Studies have shown that protein intake reduces cholesterol levels in circulation, and the mechanisms which have been attributed to this effect may be related to a reduction in total cholesterol synthesis [40]. Apparently, the bioactive peptides produced by an incomplete digestion of the protein affect cholesterol absorption in the digestive tract or have a direct effect on cholesterol synthesis and/or LDL receptor activity (LDLR) [41, 42].

Cereal grains are one of the most important sources of protein, and the storage proteins of these grains (prolamins) contain bioactive fragments. The bioactivity of these proteins has been extensively reviewed and it has been reported that prolamins are potential precursors of antihypertensive peptides [15]. Also, it has been found that the antioxidant activity of some peptides derived from whey or grains such as wheat may be attributed principally to hydrophobic amino acids such as leucine, proline, and also histidine [43, 44]. In the case of kafirin supplemented diets with cholesterol added, the antioxidant activity was kept at constant levels in circulation and even slightly higher than those achieved by the control group. This increase in serum antioxidant capacity may be related to the in vivo dietary ingested kafirin digestion, thus generating bioactive peptides with antioxidant activity that may be able to maintain serum levels of total cholesterol.

Another interesting result obtained in our study was the increase in TC values in the sorghum flour (5 and 10\%) dietary groups fed with cholesterol, compared to the cholesterol group. Several authors have reported that this behavior had a positive influence on the inhibition of atherosclerosis $[45,46]$. The mechanisms that could explain this are related to the inhibition of CETP (cholesteryl ester transfer protein), which is responsible for cholesterol esters of HDL transfer to other cholesterol fractions. When CETP is inhibited, there is accumulation of HDL-C, which has been recognized as antiatherogenic [47].

\section{Conclusion}

Our results demonstrated that sorghum kafirin extract had a good antioxidant potential in both in vitro and in vivo studies. The densitometric assay from electrophoresis pattern of kafirin fraction of sorghum flour showed that higher $\alpha$ kafirins proportion in respect to other kafirins was found. Therefore, $\alpha$-kafirins could be responsible of the antioxidant activity observed in vitro. The in vivo study confirmed that sorghum kafirin reduced the TC levels and increased the HDL-C levels in hyperlipidemic rats, suggesting that sorghum kafirin fraction can potentially reduce the risk of 
CVD. We concluded that sorghum flour consumption at the levels studied apparently protect against an atherosclerotic event.

\section{Conflict of Interests}

The authors declare that there is no conflict of interests.

\section{Acknowledgments}

This work was carried out with the support of PROINNOVA grant (Project no. 218169). Raquel A. Ortíz Cruz received scholarship from CONACyT (National Research and Technology Council) Mexico.

\section{References}

[1] Ó. V. Monroy, F. S. B. Aldatz, A. F. R. Guerra et al., "Morbilidad y mortalidad de la enfermedad isquémica del corazón y cerebrovascular en México," Archivos de Cardiología de México, vol. 77, no. 1, pp. 31-39, 2007.

[2] World Health Organization, 2015, http://www.who.int/cardiovascular_diseases/publications/en/.

[3] M. L. Daviglus, G. A. Talavera, M. L. Avilés-Santa et al., "Prevalence of major cardiovascular risk factors and cardiovascular diseases among Hispanic/Latino individuals of diverse backgrounds in the United States," JAMA: Journal of the American Medical Association, vol. 308, no. 17, pp. 1775-1784, 2012.

[4] H. Li, S. Horke, and U. Förstermann, "Oxidative stress in vascular disease and its pharmacological prevention," Trends in Pharmacological Sciences, vol. 34, no. 6, pp. 313-319, 2013.

[5] M. Frombaum, S. Le Clanche, D. Bonnefont-Rousselot, and D. Borderie, "Antioxidant effects of resveratrol and other stilbene derivatives on oxidative stress and NO bioavailability: potential benefits to cardiovascular diseases," Biochimie, vol. 94, no. 2, pp. 269-276, 2012.

[6] N. A. Strobel, R. G. Fassett, S. A. Marsh, and J. S. Coombes, "Oxidative stress biomarkers as predictors of cardiovascular disease," International Journal of Cardiology, vol. 147, no. 2, pp. 191-201, 2011.

[7] R. K. Price, J. M. Wallace, L. L. Hamill et al., "Evaluation of the effect of wheat aleurone-rich foods on markers of antioxidant status, inflammation and endothelial function in apparently healthy men and women," The British Journal of Nutrition, vol. 108, no. 9, pp. 1644-1651, 2012.

[8] E. Q. Ye, S. A. Chacko, E. L. Chou, M. Kugizaki, and S. Liu, "Greater whole-grain intake is associated with lower risk of type 2 diabetes, cardiovascular disease, and weight gain," The Journal of Nutrition, vol. 142, no. 7, pp. 1304-1313, 2012.

[9] A. Chandrasekara and F. Shahidi, "Inhibitory activities of soluble and bound millet seed phenolics on free radicals and reactive oxygen species," Journal of Agricultural and Food Chemistry, vol. 59, no. 1, pp. 428-436, 2011.

[10] P. Van Hung, "Phenolic compounds of cereals and their antioxidant capacity," Critical Reviews in Food Science and Nutrition, 2014.

[11] A. Cavazos and E. Gonzalez de Mejia, "Identification of bioactive peptides from cereal storage proteins and their potential role in prevention of chronic diseases," Comprehensive Reviews in Food Science and Food Safety, vol. 12, no. 4, pp. 364-380, 2013.
[12] D. A. Abugri, B. J. Tiimob, V. A. Apalangya, G. Pritchett, and W. H. McElhenney, "Bioactive and nutritive compounds in Sorghum bicolor (Guinea corn) red leaves and their health implication," Food Chemistry, vol. 138, no. 1, pp. 718-723, 2013.

[13] L. Dykes, W. L. Rooney, and L. W. Rooney, "Evaluation of phenolics and antioxidant activity of black sorghum hybrids," Journal of Cereal Science, vol. 58, no. 2, pp. 278-283, 2013.

[14] I. Camargo Filho, D. A. G. Cortez, T. Ueda-Nakamura, C. V. Nakamura, and B. P. Dias Filho, "Antiviral activity and mode of action of a peptide isolated from Sorghum bicolor," Phytomedicine, vol. 15, no. 3, pp. 202-208, 2008.

[15] V. Kamath, S. Niketh, A. Chandrashekar, and P. S. Rajini, "Chymotryptic hydrolysates of $\alpha$-kafirin, the storage protein of sorghum (Sorghum bicolor) exhibited angiotensin converting enzyme inhibitory activity," Food Chemistry, vol. 100, no. 1, pp. 306-311, 2007.

[16] B. H. Sarmadi and A. Ismail, "Antioxidative peptides from food proteins: a review," Peptides, vol. 31, no. 10, pp. 1949-1956, 2010.

[17] A. Lopez, C. Fernando, Z. Lazarova, R. Bañuelos, and S. H. Sánchez, "Antioxidantes, un paradigma en el tratamiento de enfermedades," Revista ANACEM (Impresa), vol. 6, no. 1, pp. 48-53, 2012.

[18] K. Sugamura and J. F. Keaney Jr., "Reactive oxygen species in cardiovascular disease," Free Radical Biology and Medicine, vol. 51, no. 5, pp. 978-992, 2011.

[19] H. Mazhar, A. Chandrashekar, and H. S. Shetty, "Isolation and immunochemical characterization of the alcohol-extractable proteins (Kafirins) of Sorghum bicolor (L.) Moench," Journal of Cereal Science, vol. 17, no. 1, pp. 83-93, 1993.

[20] U. K. Laemmli, "Cleavage of structural proteins during the assembly of the head of bacteriophage T4," Nature, vol. 227, no. 5259, pp. 680-685, 1970.

[21] A. Nunes, I. Correia, A. Barros, and I. Delgadillo, "Sequential in vitro pepsin digestion of uncooked and cooked sorghum and maize samples," Journal of Agricultural and Food Chemistry, vol. 52, no. 7, pp. 2052-2058, 2004.

[22] E. F. Moran-Palacio, O. Tortoledo-Ortiz, G. A. Yañez-Farias et al., "Determination of amino acids in medicinal plants from Southern Sonora, Mexico," Tropical Journal of Pharmaceutical Research, vol. 13, no. 4, pp. 601-606, 2014.

[23] R. M. Robles-Sánchez, M. A. Islas-Osuna, H. Astiazarán-García et al., "Quality index, consumer acceptability, bioactive compounds, and antioxidant activity of fresh-cut 'Ataulfo' mangoes (Mangifera indica L.) as affected by low-temperature storage," Journal of Food Science, vol. 74, no. 3, pp. S126-S134, 2009.

[24] J. M. Shull, J. J. Watterson, and A. W. Kirleis, "Purification and immunocytochemical localization of kafirins in Sorghum bicolor (L. Moench) endosperm," Protoplasma, vol. 171, no. 1-2, pp. 64-74, 1992.

[25] I. Correia, A. Nunes, A. S. Barros, and I. Delgadillo, "Comparison of the effects induced by different processing methods on sorghum proteins," Journal of Cereal Science, vol. 51, no. 1, pp. 146-151, 2010.

[26] L. Mehlo, Z. Mbambo, S. Bado et al., "Induced protein polymorphisms and nutritional quality of gamma irradiation mutants of sorghum," Mutation Research: Fundamental and Molecular Mechanisms of Mutagenesis, vol. 749, no. 1-2, pp. 66-72, 2013.

[27] J. M. Shull, J. J. Watterson, and A. W. Kirleis, "Proposed nomenclature for the alcohol-soluble proteins (Kafirins) of Sorghum bicolor (L. Moench) based on molecular weight, solubility, and structure," Journal of Agricultural and Food Chemistry, vol. 39, no. 1, Article ID 12449, pp. 83-87, 1991. 
[28] J. Mosse, J. C. Huet, and J. Baudet, "The amino acid composition of whole sorghum grain in relation to its nitrogen content," Cereal Chemistry, vol. 65, no. 4, pp. 271-277, 1988.

[29] J. R. N. Taylor and L. Schüssler, "The protein compositions of the different anatomical parts of sorghum grain," Journal of Cereal Science, vol. 4, no. 4, pp. 361-369, 1986.

[30] P. S. Belton, I. Delgadillo, N. G. Halford, and P. R. Shewry, "Kafirin structure and functionality," Journal of Cereal Science, vol. 44, no. 3, pp. 272-286, 2006.

[31] M. P. Oria, B. R. Hamaker, and J. M. Schull, "In vitro protein digestibility of developing and mature sorghum grain in relation to $\alpha$-, $\beta$-, and $\gamma$-kafirin disulfide crosslinking," Journal of Cereal Science, vol. 22, no. 1, pp. 85-93, 1995.

[32] J. Xiao, Y. Li, J. Li, A. P. Gonzalez, Q. Xia, and Q. Huang, "Structure, morphology, and assembly behavior of kafirin," Journal of Agricultural and Food Chemistry, vol. 63, no. 1, pp. 216-224, 2015.

[33] R. Coda, C. G. Rizzello, D. Pinto, and M. Gobbetti, "Selected lactic acid bacteria synthesize antioxidant peptides during sourdough fermentation of cereal flours," Applied and Environmental Microbiology, vol. 78, no. 4, pp. 1087-1096, 2012.

[34] A. T. Girgih, C. C. Udenigwe, and R. E. Aluko, "Reversephase HPLC separation of Hemp seed (Cannabis sativa L.) protein hydrolysate produced peptide fractions with enhanced antioxidant capacity," Plant Foods for Human Nutrition, vol. 68, no. 1, pp. 39-46, 2013.

[35] C. C. Udenigwe and R. E. Aluko, "Chemometric analysis of the amino acid requirements of antioxidant food protein hydrolysates," International Journal of Molecular Sciences, vol. 12, no. 5, pp. 3148-3161, 2011.

[36] T. Damgaard, R. Lametsch, and J. Otte, "Antioxidant capacity of hydrolyzed animal by-products and relation to amino acid composition and peptide size distribution," Journal of Food Science and Technology, vol. 52, no. 10, pp. 6511-6519, 2015.

[37] K. Erdmann, B. W. Y. Cheung, and H. Schröder, "The possible roles of food-derived bioactive peptides in reducing the risk of cardiovascular disease," Journal of Nutritional Biochemistry, vol. 19, no. 10, pp. 643-654, 2008.

[38] J. M. Awika, L. W. Rooney, X. Wu, R. L. Prior, and L. CisnerosZevallos, "Screening methods to measure antioxidant activity of sorghum (Sorghum bicolor) and sorghum products," Journal of Agricultural and Food Chemistry, vol. 51, no. 23, pp. 6657-6662, 2003.

[39] T. P. Carr, C. L. Weller, V. L. Schlegel, S. L. Cuppett, D. M. Guderian, and K. R. Johnson, "Grain sorghum lipid extract reduces cholesterol absorption and plasma non-HDL cholesterol concentration in hamsters," Journal of Nutrition, vol. 135, no. 9, pp. 2236-2240, 2005.

[40] L. Yang, J.-H. Chen, T. Xu, M.-H. Nie, and H.-K. Yang, "Hypocholesterolemic effect of rice protein is due to regulating hepatic cholesterol metabolism in adult rats," Gene, vol. 512, no. 2, pp. 470-476, 2013.

[41] S. Mendonça, P. H. Saldiva, R. J. Cruz, and J. A. G. Arêas, "Amaranth protein presents cholesterol-lowering effect," Food Chemistry, vol. 116, no. 3, pp. 738-742, 2009.

[42] H. Zheng, G. E. Bartley, C. R. Mitchell, H. Zhang, and W. Yokoyama, "Lower weight gain and hepatic lipid content in hamsters fed high fat diets supplemented with white rice protein, brown rice protein, soy protein, and their hydrolysates," Journal of Agricultural and Food Chemistry, vol. 59, no. 20, pp. 10927-10933, 2011.
[43] R. He, A. Alashi, S. A. Malomo et al., "Antihypertensive and free radical scavenging properties of enzymatic rapeseed protein hydrolysates," Food Chemistry, vol. 141, no. 1, pp. 153-159, 2013.

[44] J.-S. Wang, M.-M. Zhao, Q.-Z. Zhao, and Y.-M. Jiang, "Antioxidant properties of papain hydrolysates of wheat gluten in different oxidation systems," Food Chemistry, vol. 101, no. 4, pp. 1658-1663, 2007.

[45] F. Blachier, A. H. Lancha Jr., C. Boutry, and D. Tomé, "Alimentary proteins, amino acids and cholesterolemia," Amino Acids, vol. 38, no. 1, pp. 15-22, 2010.

[46] S. H. Lee, I.-M. Chung, Y.-S. Cha, and Y. Park, "Millet consumption decreased serum concentration of triglyceride and Creactive protein but not oxidative status in hyperlipidemic rats," Nutrition Research, vol. 30, no. 4, pp. 290-296, 2010.

[47] P. J. Barter, H. B. Brewer Jr., M. J. Chapman, C. H. Hennekens, D. J. Rader, and A. R. Tall, "Cholesteryl ester transfer protein: a novel target for raising HDL and inhibiting atherosclerosis," Arteriosclerosis, Thrombosis, and Vascular Biology, vol. 23, no. 2, pp. 160-167, 2003. 

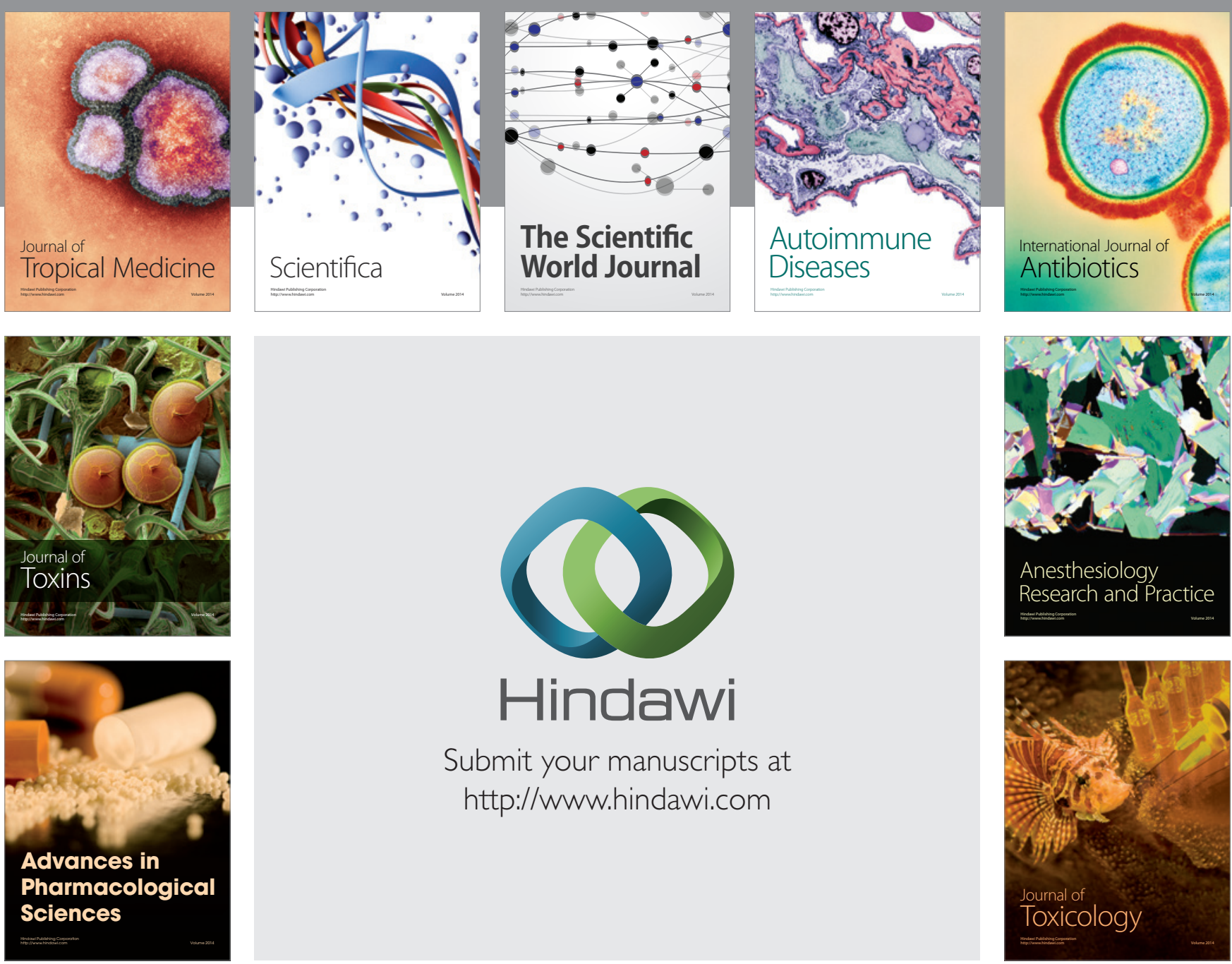

\section{Hindawi}

Submit your manuscripts at

http://www.hindawi.com
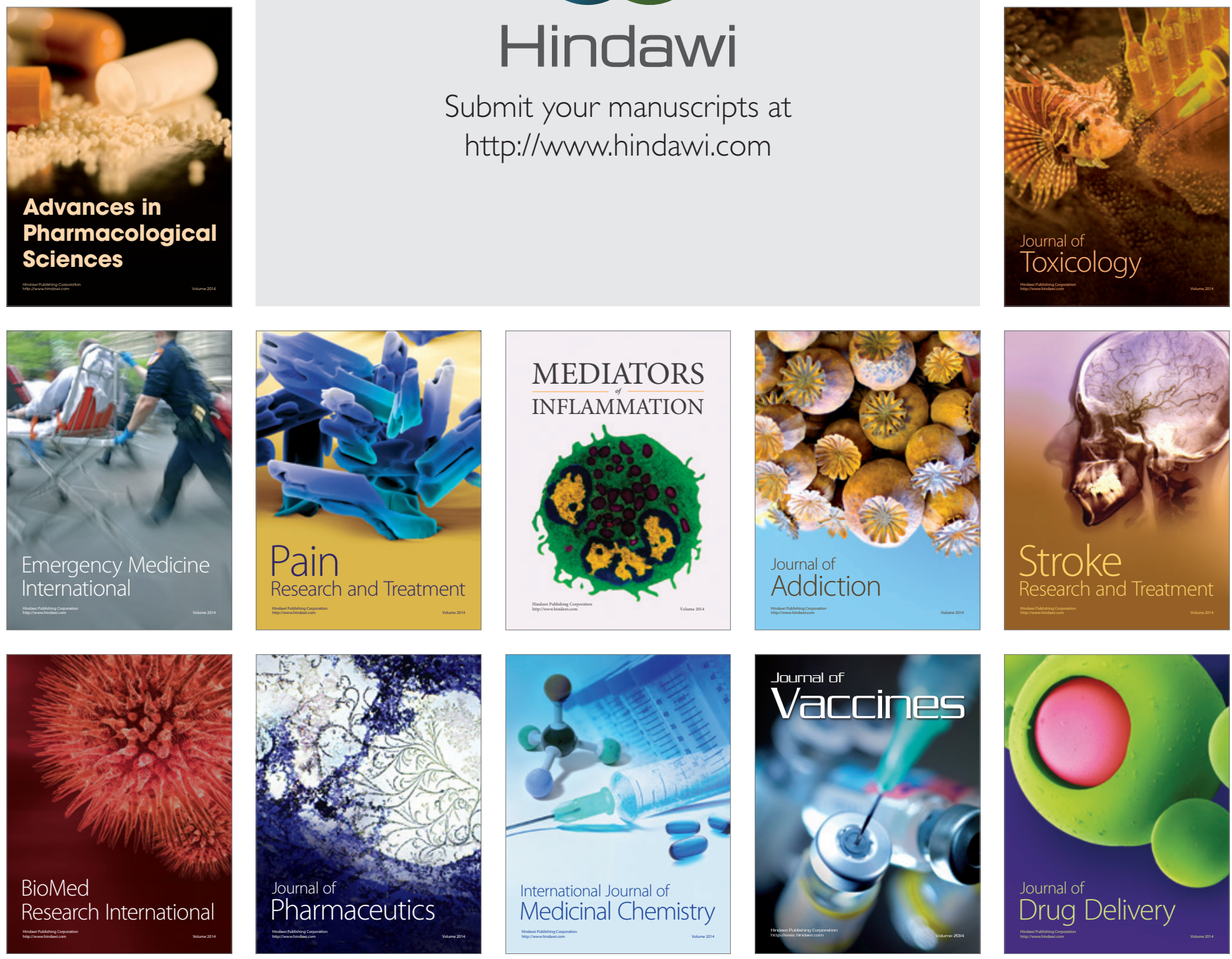